\title{
Lead accumulation in oyster mushroom, Pleurotus tuber-regium (Sing) from a continuously lead contaminated soil
}

\author{
Anyakorah CI ${ }^{1}$, Nwude $D^{2}$ and Jinadu $\mathrm{T}^{3}$ \\ ${ }^{1}$ Department of Biotechnology, Bells University of Technology, PMB 1015 Ota, Ogun State, Nigeria \\ ${ }^{2}$ Department of Biological Sciences Bells University of Technology, PMB 1015 Ota, Ogun State, Nigeria \\ ${ }^{3}$ Department of Chemical Sciences Bells University of Technology, PMB 1015 Ota, Ogun State, Nigeria
}

Anyakorah CI, Nwude D, Jinadu T 2015 - Lead accumulation in oyster mushroom, Pleurotus tuber-regium (Sing) from a continuously lead contaminated soil. Mycosphere 6(2), 145-149, Doi 10.5943/mycosphere/6/2/4

\begin{abstract}
The effect of continuous lead contamination on lead accumulation, growth of oyster mushroom Pleurotus tuber-regium and its implication for bioremediation is studied. $P$. tuberregium sclerotium was grown in soil continuously contaminated with lead at 50, 55 and 60ppm respectively. Dried soil and mushrooms were acid digested and analyzed for lead using flame atomic absorption spectrophotometer. The results showed that lead in soil increased as the contamination level was increased. The highest lead accumulation in soil and mushroom were $500 \pm 0.41 \mathrm{ppm}$ and $85 \pm 0.03 \mathrm{ppm}$ respectively. Fruit body emergence was faster in contaminated soil except at $60 \mathrm{ppm}$. Contaminated soil recorded higher mushroom fresh weight $(9.2 \pm 1.79-$ $15.9 \pm 1.55 \mathrm{~g})$ and \%ash $(10.83 \pm 0.03-18.85 \pm 0.04 \%)$ than the control $(6.6 \pm 0.49 \mathrm{~g}$ and $8.48 \pm 0.02$ $\%)$. Bioaccumulation factor was 0.12 to 0.48 indicating that $P$ tuber-regium cannot be employed in bioremediation of a continuously lead contaminated soil.
\end{abstract}

Key words - Bioaccumulation - fruit body - growth - heavy metal - sclerotium

\section{Introduction}

Lead is a naturally occurring toxic heavy metal found in the environment. Heavy metal pollution poses a serious threat to the environment, public and soil health. The use of rudimentary mining methods for extraction of gold ore from rocks in Zamfara State, Northwest Nigeria, has resulted in an epidemic of lead poisoning (Fig. 1). Between March and June 2010, lead poisoning accounted for more than 163 deaths including 111 children in that community. This also has contributed to high rates of infertility and miscarriages among affected adults (Anonymous 2013). Fungi, algae, bacteria, plant and activated sludge have demonstrated great potential as metal biosorbent due to their metal sequestering properties which can decrease the concentrations of heavy metal ions in soil (Nilanjana Das et al. 2008). Accumulation of metals by biological species has been attributed to physiology of the organisms. Mushrooms have comparatively remarkable ability to accumulate high concentration of metallic elements and could be employed for a more sustainable and effective intervention in remediation of polluted environment (Fourest \& Roux 1992, Falandayzs \& Chwir 1997, Falandayzs et al. 2003, Isikhuemhen et al. 2003). The purpose of 
this study was to investigate the effect of continuous artificial lead contamination of soil on the growth and lead accumulation in $P$ tuber-regium and its implication for bioremediation.

\section{Materials \& Methods}

\section{Collection of materials}

Sclerotia of Pleurotus tuber-regium were procured from a local market, Nwagu market in Agulu, Anambra State, Nigeria while loamy soil was collected from Bells University of Technology, Ota, Ogun State. Plastic bowls used for seeding were bought from Ojuore market in Ota, Ogun State, Nigeria.

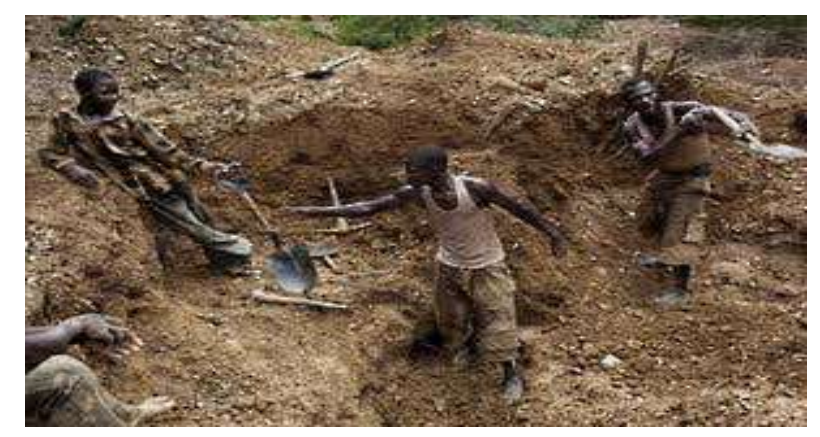

Fig. 1 - Anthropogenic activity in a gold mining site in Zamfara State, Nigeria (Anonymous 2013)

\section{Substrate preparation and inoculation}

Soil was sieved with $1 \mathrm{~mm}$ mesh size and $1 \mathrm{~kg}$ was distributed in to perforated plastic bowls measuring $20 \mathrm{~cm}$ diameter. Preparations of 50, 55 and $60 \mathrm{ppm} \mathrm{PbO}$ were constituted. Treatments were four: soil + sclerotia, soil $+50 \mathrm{ppm} \mathrm{Pb}+$ sclerotia, soil $+55 \mathrm{ppm} \mathrm{Pb}+$ sclerotia and soil + $60 \mathrm{ppm}+$ sclerotia. The sclerotia were soaked in water for $18 \mathrm{hrs}$ and cut into $30 \mathrm{~g}$ sizes before seeding in to soil treated with approximately $500 \mathrm{ml}$ of respective lead ion concentration. The plastic bowls were kept at room temperature $\left(28^{\circ} \mathrm{C} \pm 2^{\circ} \mathrm{C}\right)$ on laboratory bench top. Subsequent watering was done with the respective lead ion solutions at the rate of $100 \mathrm{ml} / 48$ hours. Oyster mushroom was harvested from all treatments; fresh weights were taken and dried at $50^{\circ} \mathrm{C}$ for $24 \mathrm{hrs}$. The time for fruit body emergence was noted and \% ash determined according to AOAC (1990).

\section{Determination of Lead in fruit body and soil}

Lead accumulation in fruit body and the soil was analyzed by atomic absorption spectrophotometer (BUCH Scientific Model 210) according to the method of Crosby (1977) and AOAC (1990). Dried samples were homogenized in a precleaned mortar, sieved and $2 \mathrm{~g}$ sample were ashed in a muffle furnace at $550^{\circ} \mathrm{C}-600^{\circ} \mathrm{C}$ for $12-18 \mathrm{hrs}$. The ash was digested with $10 \mathrm{ml}$ nitric acid $\left(\mathrm{HNO}_{3}\right)(65 \%)$ and $5 \mathrm{ml}$ perchloric acid $\left(\mathrm{HClO}_{4}\right)(70 \%)$ on a hot plate for $40 \mathrm{mins}$, filtered with whatman filter paper and diluted to $100 \mathrm{ml}$ with deionized water before lead determination.

\section{Results and Discussion}

\section{Fruit body emergence}

Fruit body emergence was faster in lead contaminated soil which could be an indication of tolerance of the mushroom to continuous lead contamination (Fig. 2). Similar effect of lead tolerance by Pleurotus tuber-regium was observed by Akpaja et al (2012) at $0.5 \mathrm{mmol}$ lead contamination. Lead is reported to be tolerated by species of Aspergillus (Valix et al. 2000, Ezzouhri et al. 2009) and Armillaria (Rigling et al. 2006). Red clover plants cultivated in $50 \mathrm{mg} \mathrm{Pb}$ kg-1 soil was also reported to be well developed with numerous nodules (Stan et al (2011). These 
reports are contrary to the work of Wargo \& Carey (2001) and Majer et al. (2002) who reported that rhizomorph production by Armillaria ostoyae was inhibited in natural soils containing high concentrations of heavy metals, particularly lead. They concluded that lead contaminated soils reduced soil fertility, directly affected changes of physiological indices which caused a decline in mushroom yield. These contradictory reports could be due to the use of different species and experimental conditions.

\section{Fresh weight}

Fresh weight and \%ash of all harvested mushrooms from lead contaminated soil were higher than the control (Figs. $2 \& 3$ ). This is also an indication that P. tuber-regium could grow in continuous lead contaminated soil. Highest and lowest weights in contaminated soil were recorded at 50 and 60ppm contamination respectively. The increase in weight and ash content could be associated with lead accumulation in the mushroom. The result agreed with the finding of Kalac \& Svoboda (2000), Ita et al. (2006) and Kalac (2010) who reported that increase in mass of fruit body of wild and edible mushroom was associated with the concentration of metals. Although Akpaja et al. (2012) reported that lead greatly affected $P$. tuber-regium morphometry. The contradiction could be associated with the concentration and type of lead used. While 50-60ppm PbO was used in this work, the former used 0.125-2.0 mmol $\mathrm{PbSO}_{4}$.

\section{Lead Accumulation in soil and mushroom}

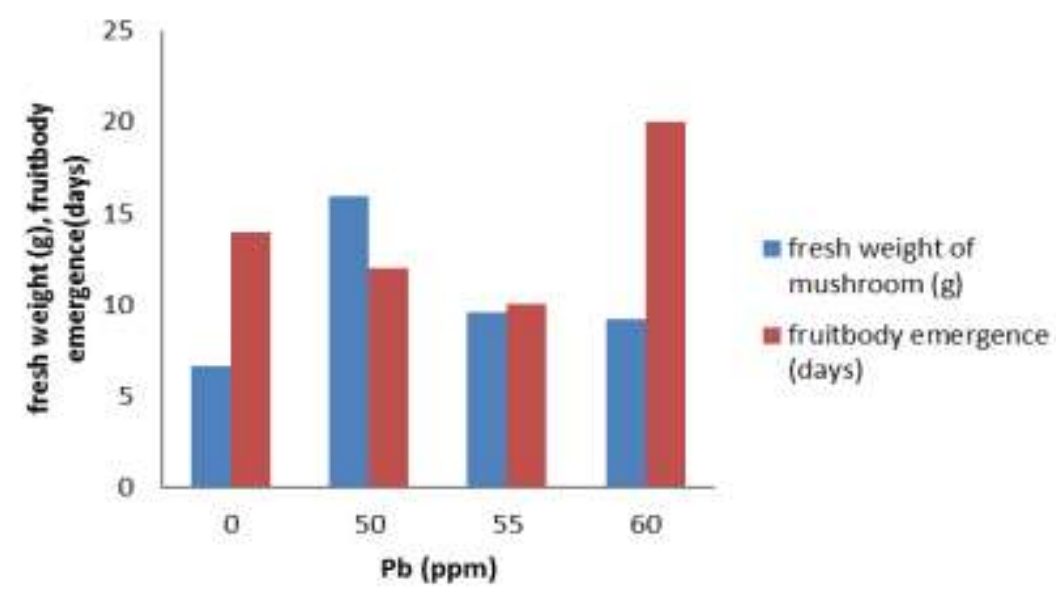

Fig. 2 - Fresh weight of mushroom and fruit body emergence in lead contaminated soil

Lead accumulation was more in soil than in mushroom fruit body (Fig. 4) and increased with increased contamination levels. The range in lead values in soil and mushroom was $145.0 \pm 0.57,165.0 \pm 1.15,463.0 \pm 0.82,500.0 \mathrm{ppm} \pm 1.41$ and $25.0 \pm 0.13,80.0 \pm 0.16,85.0 \pm 0,03$, $60.0 \pm 0.35 \mathrm{ppm}$ respectively. Edible and wild mushrooms have been shown to accumulate high concentrations of toxic metallic elements even when the concentration of such metal is low in the soil (Falandayzs \& Chwir 1997, Falandayzs et al. 2003). Cantharellus cibarius, a mushroom widely used in European cuisine was reported to accumulate $4.86 \mathrm{~g} / \mathrm{g}$ lead in its tissue. The values of lead in the studied mushroom exceeded recommended EU acceptable standard of $3 \mathrm{mg} \mathrm{Kg}^{-1}$ so mushrooms collected from such environment should not be consumed. The bioaccumulation factor of metals is a ratio of the metal concentration in the fruit body to the metal in the soil and is an indication of rate of accumulation of metal by mushroom. For a biological specie to be used in bioremediation, it must have a bioaccumulation factor of 1 and above. Bioaccumulation factor of lead in this work has values between 0.12 and 0.48 which are not important for bioremediation. This is similar to the finding of Ringling et al. (2006) who obtained a bioaccumulation factor of 
$0.009-0.27 \mathrm{mgKg}^{-1}$ in Armillaria. This could be an indication that $P$. tuber-regium may not be efficient as a lead bio-sorbent in a continuously lead contaminated soil at the studied concentration.

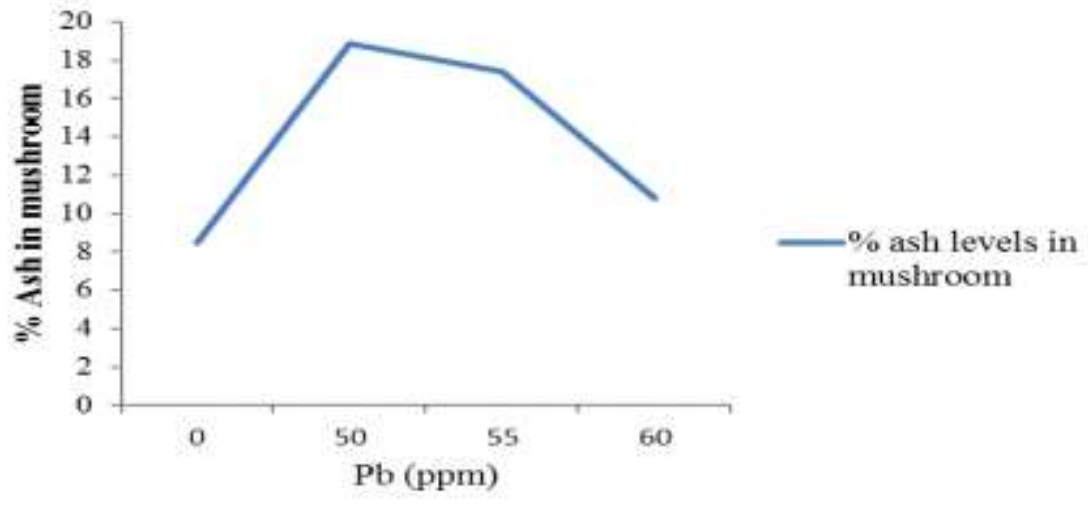

Fig. 3 - \% Ash of mushroom in lead contaminated soil

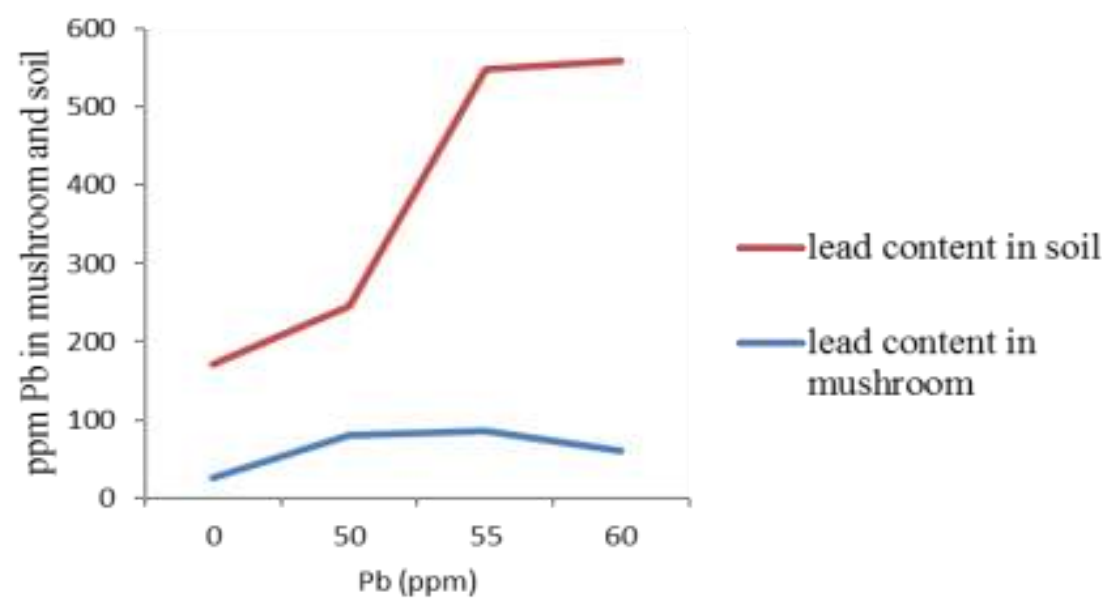

Fig. 4 - Lead accumulation in mushroom and soil

Table 1 Fruit body emergence, fresh weight of mushroom, \%ash in mushroom, lead in soil and lead in mushroom at 0,5055 and $60 \mathrm{ppm}$ respectively

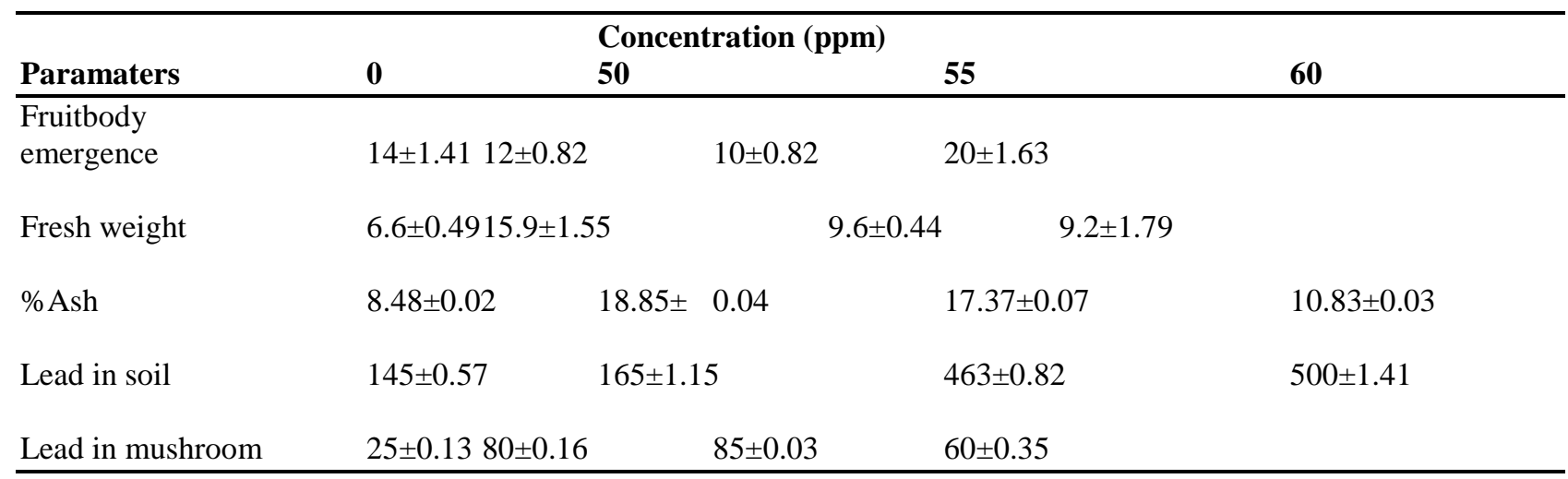

\section{Acknowledgement}

This work was financed by Bells University of Technology, Ota Ogun State, Nigeria.

\section{References}


Akpaja EO, Nwogu NA, Odibo EA. 2012 - Effect of heavy metals on the growth and development of Pleurotus tuber-regium. Mycosphere 3(1), 57-60.

Anonymous 2013 - health in action: Lead poisoning in Northern Nigeria-Centers for Disease Control and Prevention. http://www.cdc.gov/onehealth/inaction/lead-poisoning.html (accessed 25 September 2014).

AOAC 1990 - Official Methods of Analysis (15 ${ }^{\text {th }}$ Edition) Washington DC Association of Official Analytical Chemists.

Crosby WT 1977 - Determination of metals in foods. A review. The Analyst 102, 223-268.

Ezzouhri L, Castro E, Moya M, Espinola F, Lairini K. 2009 - Heavy metal tolerance of filamentous fungi isolated from polluted sites in Tangier, Morocco. African Journal of Microbiology Research 3(2), 35-48.

Falandyzs J, Chwir A. 1997 - The concentrations and bio concentrations factors for mercury in mushrooms from the Mierzeja Wislana sandbar, Northern Poland. Science of the Total Environment 203, 221-228.

Falandayzs J, Kawano A, Swieczkowski A, Brzostowski A,Dadej M. 2003 - Total mercury in wildgrown higher mushrooms and underlying soil from Wdzydze landscape parc. Northern Poland Food Chemistry 81, 21-26.

Fourest E, Roux JC. 1992 - Heavy metal biosorption by fungal mycelial byproducts: mechanism and influence of pH. Applied Microbiology and Biotechnology 37, 399-403.

Isikhuemhen OS, Anoliefo GO, Oghale OI. 2003 - Bioremediation of crude oil polluted soil by the white rot fungus, Pleurotus tuber-regium(Fr.) Sing. Environmental Science \& Pollution Research10, 108-112.

Ita BN, Essien JP, Ebong GA. 2006 - Heavy metal levels in fruiting bodies of edible and nonedible mushrooms from the Niger Delta Region of Nigeria. Journal of Agriculture, forestry and Social Science 2, 84-87.

Kalač P. 2010 - Trace element contents in European species of wild growing edible mushrooms: a review for the period 2000-2009. Food Chemistry 122(1), 2-15.

Kalač P, Svoboda LR. 2000 - A review of trace element concentrations in edible mushrooms. Food Chemistry 69(3), 273-281. Nilanjana D, Vimala R, Karthika P. 2008Biosorption of heavy metals. Indian Journal of Biotechnology 7, 159-160.

Majer BJ, Tscherko D, Paschke A. 2002 - Effects of heavy metal contamination of soils on micro nucleus induction in Tradescantia and on microbial enzyme activities: a comparative investigation. Mutation Research 515, 111-124.

Rigling D, Madeleine S,Günthardt G, Hélène B, Beat F. 2006 - Accumulation of heavy metals into Armillaria rhizomorphs from contaminated soils. Forest Snow and Landscape Research 80(2), 213-220.

Stan V, Gament E, Cornea C, Voaides C, Dusai M, Plopeanu G. 2011 - Effects of Heavy Metal from Polluted Soils on the Rhizobium Diversity. Notulae Botanicae Horti Agrobotanici Cluj-Napoca 39(1), 88-95.

Valix M, Tang JY, Malik R. 2000 - Heavy Metal Tolerance of Fungi. Minerals Engineering 2000, 499-505.

Wargo PM, Carey AC. 2001 Effects of metals and pH on in vitro growth of Armillaria ostoyae and other root and butt rot fungi of red spruce. Forest Pathology 41, 5-24. 